\title{
Diversity of ethanol fermenting yeasts in coconut inflorescence sap and their application potential
}

\author{
Nichanun Udomsaksakul ${ }^{\mathrm{a}}$, Kentaro Kodama ${ }^{\mathrm{b}}$, Somboon Tanasupawat ${ }^{\mathrm{c}}$, Ancharida Savarajara ${ }^{\mathrm{d}, *}$ \\ ${ }^{a}$ Program in Biotechnology, Faculty of Science, Chulalongkorn University, Bangkok 10330 Thailand \\ b The Institute of Biotechnology and Genetic Engineering, Chulalongkorn University, \\ Bangkok 10330 Thailand \\ c Department of Biochemistry and Microbiology, Faculty of Pharmaceutical Sciences, \\ Chulalongkorn University, Bangkok 10330 Thailand \\ d Department of Microbiology, Faculty of Science, Chulalongkorn University, Bangkok 10330 Thailand
}

*Corresponding author, e-mail: sanchari@chula.ac.th

Received 28 Nov 2017

Accepted 6 Oct 2018

\begin{abstract}
Ten ethanol fermenting yeast species: Saccharomyces cerevisiae, Lachancea fermentati, Pichia kudriavzevii, Shizosaccharomyces pombe, Candida tropicalis, Zygosaccharomyces rouxii, Saccharomycodes ludwigii, Hanseniaspora guilliermondii, Wickerhamomyces anomalus and P. manshurica were isolated from coconut inflorescence sap in Thailand. Saccharomyces cerevisiae was found to be the dominant species (65\%), where $30 \%$ of the $S$. cerevisiae strains isolated could grow at $40^{\circ} \mathrm{C}$, strain NT029 gave the highest ethanol yield $(64.5 \mathrm{~g} / \mathrm{l})$ and strain NC018 had the desired characteristics of a baker's yeast strain (high $\mathrm{CO}_{2}$ production, high biomass yield and fast flocculation). Evidently, bread prepared by strain NC018 showed a good texture. Furthermore, S. cerevisiae NC027 was suitable for ethanol production, with maximum ethanol yields (66.92 and $102.26 \mathrm{~g} / \mathrm{l}$ ) and ethanol productivity levels $(1.39 \mathrm{and} 2.13 \mathrm{~g} / \mathrm{l} / \mathrm{h}$ ) in medium containing $18 \%(\mathrm{w} / \mathrm{v})$ glucose and $10 \%(\mathrm{w} / \mathrm{v})$ molasses at $30^{\circ} \mathrm{C}$, which were higher than the reference ethanol producing strain, S. cerevisiae TISTR 5596. Finally, S. cerevisiae NL026 assimilated glycerol, which may indicate its potential as a value addition strain for fermentation of low-price glycerol waste.
\end{abstract}

KEYWORDS: baker's yeast, ethanol production, glycerol, Saccharomyces cerevisiae

\section{INTRODUCTION}

Coconut inflorescence sap (CIS) is the exudate from the unopened inflorescence of coconut palm (Cocos nucifera). The inflorescences of coconut palm are bound tightly by their spathe to prevent them from opening for 3 weeks, so the spathe is cut (around $5 \mathrm{~cm}$ from top end) to obtain the sap. In Thailand, the CIS that oozes out of the treated inflorescence is traditionally collected in a bamboo tube. Each time a CIS collection is made, an end of the inflorescence axis is cut off as a thin slice and a fresh bamboo tube is replaced, which is typically done twice daily. The cut inflorescence axis can secrete about 41 /day of sap over a period of about 2 months ${ }^{12}$. The CIS is a yellowish-brown clear liquid of $\mathrm{pH} 7.0$ and contains $12-15 \%(\mathrm{w} / \mathrm{w})$ sucrose, approximately $0.23 \%$ $(\mathrm{w} / \mathrm{w})$ protein, $0.02 \%(\mathrm{w} / \mathrm{w})$ fat, trace amounts of glucose, fructose, maltose and raffinose, and is relatively rich in $\mathrm{Na}$ and $\mathrm{K}$ ions ${ }^{6}$. As soon as the CIS trickles down the bamboo tube, spontaneous fermentation by microorganisms occurs.
Strains of $S$. cerevisiae are used for bread making because they can ferment all the sugars present in the dough to $\mathrm{CO}_{2}$, ethanol and some organic acids and esters ${ }^{20}$. These metabolites have an important role in improving the taste and texture of bread. The important properties of a high quality baker's yeast include an (i) high $\mathrm{CO}_{2}$ production rate, (ii) high invertase and maltase activities, (iii) appreciable ethanol production, (iv) ability to ferment the different kinds of sugars in the dough to $\mathrm{CO}_{2}$, (v) rapid dough leavening, (vi) rapid flocculation and (vii) appreciable osmo-and cryo-tolerance. In addition, other isolates of $S$. cerevisiae are the most commonly used microbes for bioethanol production because they give ethanol at a high yield and productivity and can withstand a high concentration of ethanol, which keeps the subsequent enrichment by distillation cost low. Ideal traits of $S$. cerevisiae for ethanol production include an (i) high ethanol production level, (ii) high ethanol tolerance, (iii) good thermotolerance, (iv) appreciable osmotolerance, 
(v) rapid start of metabolism (helps to control contamination), (vi) rapid fermentation and (vii) a slow flocculation rate (provides a long time for cells to assimilate nutrients for growth and ethanol production). Although no $S$. cerevisiae strain has all of these desirable characteristics, a few strains have been found to possess appreciable characteristics for either bread making or bioethanol production.

For every 101 of biodiesel production, about 11 of glycerol waste is produced. The industrial scale purification of this glycerol waste is economically unviable due to the high process cost and relatively low market value. Under aerobic catabolism, yeast can phosphorylate glycerol to 3-phospho-glycerol, followed by oxidation to 3phospho-dihydroxyacetone, which is then converted to 3-phospho-glyceraldehyde. The 3-phosphoglyceraldehyde enters the glycolytic pathway, where it is transformed into pyruvic acid and then into acetyl-CoA, which is the precursor of a variety of metabolic products ${ }^{3}$. Hence yeast isolates that can assimilate glycerol may have the potential to convert low cost waste glycerol to several high value metabolites.

The objective of this work was to screen for ethanol fermenting yeasts associated with CIS that may be suitable for bioethanol production, and screening of the isolated $S$. cerevisiae strains for those with the desired characteristics for bread making and glycerol assimilation.

\section{MATERIALS AND METHODS}

\section{Molasses and CIS}

Thirty-nine CIS samples were collected from SamutSongkram province, Thailand and kept at $4^{\circ} \mathrm{C}$ for no longer than $48 \mathrm{~h}$ before use. Molasses was collected from Khonburi Sugar Co. Ltd., Nakhon Ratchasima province, Thailand and kept at $4{ }^{\circ} \mathrm{C}$ until used.

\section{Isolation of CIS-fermenting yeast strains}

For each CIS sample, $1 \mathrm{ml}$ was inoculated into $5 \mathrm{ml}$ of selective medium containing ( $\% \mathrm{w} / \mathrm{v})$; glucose 2, peptone 0.3 , yeast extract (YE) 0.3 , chloramphenicol 1 and 3\% (v/v) ethanol, pH 5.6 in a $16 \times 150 \mathrm{~mm}$ test tube and incubated in an anaerobic pouch (Kenki, Mitsubishi Gas Chemicals, Japan) at $30^{\circ} \mathrm{C}$ for 5 days. The obtained culture was purified to single colonies by the streak plate method on $10 \%$ glucose agar medium containing $(\% \mathrm{w} / \mathrm{v})$; glucose 10 , peptone 0.3 , YE 0.3 , agar 2, pH 5.6 and incubated as above. Each single colony was transferred onto YM agar containing (\% w/v); glucose 1 , peptone 0.5 , YE 0.3 , malt extract 0.3 , agar $2, \mathrm{pH} 5.6$ and incubated at $30^{\circ} \mathrm{C}$ under an aerobic condition for 2 days. After incubation, the culture was kept at $4^{\circ} \mathrm{C}$ for further study.

\section{Identification of the isolated yeasts}

All the yeast strains isolated were identified to molecular operational taxonomic units by 26S rRNA (D1/D2) gene sequence analysis and then ascribed to likely species by comparison with sequences from known species using the method of Kurtzman \& Robnette $^{10}$. One loopful of yeast cells suspended in $100 \mu \mathrm{l}$ lysis buffer containing $100 \mathrm{mM}$ Tris$\mathrm{Cl}(\mathrm{pH}$ 8.0), $30 \mathrm{mM}$ EDTA (pH 8.0) and 0.5\% $(\mathrm{w} / \mathrm{v})$ SDS was boiled in a boiling water bath for $15 \mathrm{~min}$, mixed with $2.5 \mathrm{M}$ potassium acetate, $\mathrm{pH} 7.5$ $(100 \mu \mathrm{l})$, incubated in ice-water for $60 \mathrm{~min}$ then centrifuged $\left(18000 \mathrm{~g}, 4^{\circ} \mathrm{C}, 5 \mathrm{~min}\right)$. The supernatant was harvested, extracted twice with chloroform/isoamyl alcohol $(100 \mu \mathrm{l})$ and ethanol precipitated. The DNA precipitate was dried at $37^{\circ} \mathrm{C}$, dissolved in sterile water $(30 \mu \mathrm{l})$ and used as DNA template for PCR amplification using the F63 (5'-GC ATATCAATAAGCGGAGGAAAAG-3') and LR3 (5'-GG TCCGTGTTTCAAGACG $-3^{\prime}$ ) primer pair. The PCR was thermal cycled at $94^{\circ} \mathrm{C}(3 \mathrm{~min})$ followed by 35 cycles of $94^{\circ} \mathrm{C}(20 \mathrm{~s}), 52^{\circ} \mathrm{C}(30 \mathrm{~s})$ and $72^{\circ} \mathrm{C}$ (30 s), then followed by a final $72{ }^{\circ} \mathrm{C}(5 \mathrm{~min})$. The PCR product ( $600 \mathrm{bp}$ ) was purified using a Gel/PCR DNA fragment extraction kit (PCR clean up: Genaid Biotech, Taiwan) and then direct DNA sequenced commercially at Macrogen, Korea. Each obtained DNA sequence was compared for homologues using pairwise searching of GenBank with $\mathrm{BLAST}_{\mathrm{N}}$ and then aligned with the sequences retrieved from GenBank using the CLUSTALX $1.8^{24}$ multiple alignment program. A phylogenetic tree of a representative strain of each species was constructed from the evolutionary distance data, calculated by Kimura's model using the neighbour-joining method ${ }^{21}$ with 1000 random re-sampling Bootstrap analysis. The isolated yeasts that were identified as Saccharomyces cerevisiae were then further examined for their ethanol and $\mathrm{CO}_{2}$ production efficiency, thermotolerance and glycerol utilization.

\section{Determination of $\mathrm{CO}_{2}$ production}

The $\mathrm{CO}_{2}$ production efficiency of each $S$. cerevisiae strain was determined by suspending the cells grown on a YM agar slant (4.5 $\mathrm{ml} \mathrm{YM}$ agar in $16 \times 150 \mathrm{~mm}$ test tube) at $30^{\circ} \mathrm{C}$ for $48 \mathrm{~h}$ in $2 \mathrm{ml}$ of fermentation medium containing (\% w/v); $18 \%$ glucose 18 , YE 0.45 , peptone $0.75, \mathrm{pH} 5.6$, and then 
inoculating this into $50 \mathrm{ml}$ of fresh fermentation medium (in a $125-\mathrm{ml}$ Erlenmeyer flask) at a final concentration of $4 \times 10^{4}$ cells $/ \mathrm{ml}$. The inoculated medium was placed in plastic bag containing wet cotton to avoid the loss of moisture and incubated at $30^{\circ} \mathrm{C}$ for 5 days without agitation. The weight of the inoculated medium was determined immediately after the inoculation and every $24 \mathrm{~h}$ thereafter. The maximum level of $\mathrm{CO}_{2}$ production was estimated from the maximum weight loss of the culture broth during the incubation. Those $S$. cerevisiae strains that produced more than $80 \mathrm{~g} / 1 \mathrm{CO}_{2}$ were selected for further study.

\section{Determination of yeast thermotolerance}

The thermotolerance of each yeast isolate was determined from its growth rate in $10 \mathrm{ml}$ modified YPD medium containing $(\% \mathrm{w} / \mathrm{v})$; glucose 10 , peptone 0.75 , YE 0.45 , pH 5.6 in a $25 \times 200 \mathrm{~mm}$ test tube which was incubated at $37^{\circ} \mathrm{C}, 40^{\circ} \mathrm{C}$ or $45^{\circ} \mathrm{C}$ for $48 \mathrm{~h}$ with agitation at $200 \mathrm{rpm}$.

\section{Characterization of $\mathrm{CO}_{2}$ producing S. cerevisiae strains}

The morphological, physiological and biochemical characteristics of the seven isolated $S$. cerevisiae strains that produced $\mathrm{CO}_{2}$ at more than $80 \mathrm{~g} / \mathrm{l}$ were compared to the standard description of $S$. cerevisiae type strain ${ }^{9}$. Cultures grown on YM agar at $30^{\circ} \mathrm{C}$ for 2-7 days were used for examination of the colony morphology, cell shape, cell size, ascospore formation and ascospore shape. Carbon assimilation was examined by cultivating cells (final $10^{6}$ cells $/ \mathrm{ml}$ ) in $5 \mathrm{ml}$ yeast nitrogen base broth (YNB; Becton, Dickinson and Company, New Jersey, USA) supplemented with $50 \mathrm{~g} / 1$ glucose, melibiose or mannitol in a $16 \times 150 \mathrm{~mm}$ test tube and incubated at $30^{\circ} \mathrm{C}$ for 21 days without shaking. By the same token, nitrogen assimilation was examined by cultivating in yeast carbon base broth (YCB; Becton, Dickinson and Company, New Jersey, USA) supplemented with $0.5 \%(\mathrm{w} / \mathrm{v})\left(\mathrm{NH}_{4}\right)_{2} \mathrm{SO}_{4}$ or $0.078 \%(\mathrm{w} / \mathrm{v}) \mathrm{KNO}_{3}$. Vitamin requirement was determined by cultivating in vitamin free medium (United State Biological, USA). Cell growth in each of the above media was monitored every 7 days.

\section{Determination of bread dough leavening capability}

For each isolated $S$. cerevisiae strain, cells grown on a YM agar slant at $30^{\circ} \mathrm{C}$ for $48 \mathrm{~h}$ were suspended in $2 \mathrm{ml}$ of medium containing (\% $\mathrm{w} / \mathrm{v})$; molasses
16 and $\left(\mathrm{NH}_{4}\right)_{2} \mathrm{SO}_{4}$ 0.1, $\mathrm{pH} 5.6$, and then inoculated into $48 \mathrm{ml}$ of the same medium in a $250-\mathrm{ml}$ Erlenmeyer flask and incubated at $32^{\circ} \mathrm{C}, 220 \mathrm{rpm}$ for $14 \mathrm{~h}$. Then $2.5 \mathrm{ml}$ of this resultant culture was transferred to $50 \mathrm{ml}$ of the same medium in a 250 $\mathrm{ml}$ Erlenmeyer flask and incubated as above. After incubation, $150 \mathrm{ml}$ of the culture was centrifuged at $4^{\circ} \mathrm{C}, 6120 \mathrm{~g}$ for $5 \mathrm{~min}$ to harvest the cells. The obtained wet cells (pellet) were washed twice with $60 \mathrm{ml}$ of sterile $0.85 \%(\mathrm{w} / \mathrm{v})$ saline solution (SSS) and weighed. Commercial baker's yeast, Sankyo Yeast M (Sankyo, Japan) was used as the reference (control) strain.

\section{Preparation of bread}

Dough was made from $75 \mathrm{~g}$ wheat flour (Nissin Kameria Kyoriki, Japan), 3.8 g sucrose, $1.5 \mathrm{~g} \mathrm{NaCl}$, $1.9 \mathrm{~g}$ wet yeast cells and $51 \mathrm{ml}$ distilled water. The $\mathrm{NaCl}$ and sucrose were first dissolved in $46 \mathrm{ml}$ distilled water and the yeast cells were suspended in $5 \mathrm{ml}$ distilled water. The $\mathrm{NaCl} /$ sucrose solution was mixed with the wheat flour at room temperature $\left(30-32^{\circ} \mathrm{C}\right)$ for $5 \mathrm{~min}$, and then the yeast cell suspension was added and kneaded for $9 \mathrm{~min}$. The first dough fermentation was performed at $30^{\circ} \mathrm{C}$ for $50 \mathrm{~min}$, then pouched and fermented at $30^{\circ} \mathrm{C}$ for $15 \mathrm{~min}$. The dough was then put into a $500-\mathrm{ml}$ beaker, spread over with shortening, and further fermented at $37^{\circ} \mathrm{C}(50 \mathrm{~min})$ before baking at $200^{\circ} \mathrm{C}$ for $30 \mathrm{~min}$. Bread volume and texture were investigated and compared to those prepared by the reference baker's yeast.

\section{Determination of yeast osmotolerance}

Each yeast isolate was grown in modified YM broth containing (\% w/v); glucose 10, YE 0.75, peptone 0.05 , malt extract $0.3, \mathrm{pH} 5.6$ and incubated at $30^{\circ} \mathrm{C}, 200 \mathrm{rpm}$ for $24 \mathrm{~h}$. Resultant culture was transferred into $50 \mathrm{ml}$ YPD broth containing 20, 24, 26 , or $28 \%(\mathrm{w} / \mathrm{v})$ glucose in a $250-\mathrm{ml}$ Arm flask at an initial optical density at $660 \mathrm{~nm}$ (OD660) of 0.05, and incubated as above. The osmotolerance was determined from the cell growth at $24 \mathrm{~h}$. Each yeast isolate was grown in modified YM broth containing (\% w/v); glucose 10, YE 0.75, peptone 0.05 , malt extract 0.3 , pH 5.6 and incubated at $30^{\circ} \mathrm{C}, 200 \mathrm{rpm}$ for $24 \mathrm{~h}$. Resultant culture was transferred into $50 \mathrm{ml}$ YPD broth containing 20, 24, 26, or $28 \%$ $(\mathrm{w} / \mathrm{v})$ glucose in a 250-ml Arm flask at an initial optical density at $660 \mathrm{~nm}\left(\mathrm{OD}_{660}\right)$ of 0.05 , and incubated as above. The osmotolerance was determined from the cell growth at $24 \mathrm{~h}$. 


\section{Determination of ethanol tolerance}

Ethanol tolerance was determined by the same method as osmotolerance, except the culture was grown in modified YPD broth $(3 \% \mathrm{w} / \mathrm{v}$ glucose) containing ethanol at 10,13 , or $15 \%(\mathrm{v} / \mathrm{v})$.

\section{Determination of the duration of incubation before $\mathrm{CO}_{2}$ production}

Each selected yeast strain was inoculated into $6 \mathrm{ml}$ of modified YPD medium ( $6 \% \mathrm{w} / \mathrm{v}$ glucose) supplemented with $0.16 \%(\mathrm{w} / \mathrm{v})$ bromothymol blue in a $16 \times 150 \mathrm{~mm}$ test tube. A Durham tube was also placed in the medium tube to trap the released $\mathrm{CO}_{2}$ and then the inoculated medium was incubated at $30{ }^{\circ} \mathrm{C}$ without shaking for $10 \mathrm{~h}$. Production of $\mathrm{CO}_{2}$ and the colour change of the culture broth were monitored every $10 \mathrm{~min}$.

\section{Determination of the flocculation capability and rate}

Each selected yeast strain was inoculated into $10 \mathrm{ml}$ modified YPD medium (10\% w/v glucose) in a $25 \times 200 \mathrm{~mm}$ test tube and incubated at $30^{\circ} \mathrm{C}$ without shaking for $72 \mathrm{~h}$. After incubation, the culture was shaken to homogeneity and then the time required for complete flocculation was determined.

\section{Determination of glycerol assimilation}

One loopful of $S$. cerevisiae cells was inoculated into $50 \mathrm{ml}$ of YNB broth supplemented with $0.005 \%$ $(\mathrm{w} / \mathrm{v})$ glucose in a 250-ml Erlenmeyer flask and incubated at $30^{\circ} \mathrm{C}, 200 \mathrm{rpm}$ for $48 \mathrm{~h}$. The resultant culture was then diluted 100 times with SSS and $0.5 \mathrm{ml}$ of the diluted culture was transferred into $5 \mathrm{ml}$ of YNB broth, or YNB broth supplemented with either $0.5 \%(\mathrm{w} / \mathrm{v})$ glucose or glycerol in a $16 \times 150 \mathrm{~mm}$ test tube and incubated at $30^{\circ} \mathrm{C}$ without shaking for 21 days.

\section{Determination of ethanol production}

Each isolate of the high $\mathrm{CO}_{2}$ producing $S$. cerevisiae and those of which grew at $40^{\circ} \mathrm{C}$ were grown in fermentation medium and incubated at $30^{\circ} \mathrm{C}, 200 \mathrm{rpm}$ for $24 \mathrm{~h}$. The obtained culture was then transferred at $1 \%(\mathrm{v} / \mathrm{v})$ into $50 \mathrm{ml}$ of the same medium in a 250-ml Erlenmeyer flask, incubated under the same conditions for $24 \mathrm{~h}$ and used as the inoculum. The inoculum was inoculated at $10 \%(\mathrm{v} / \mathrm{v})$ final into fresh fermentation medium $(42.5 \mathrm{ml})$ in a $50-\mathrm{ml}$ Erlenmeyer flask and incubated at $30^{\circ} \mathrm{C}$ or $40^{\circ} \mathrm{C}$ under an oxygen-limited condition for $48 \mathrm{~h}$. The oxygen-limited condition was performed by cultivating $47.5 \mathrm{ml}$ of the inoculated medium in the 50-ml flask without shaking and the cotton plug of the culture flask was tightly wrapped with parafilm to be air-tight. After cultivation, the culture was centrifuged at $4{ }^{\circ} \mathrm{C}, 16700 \times g$ for $5 \mathrm{~min}$ and the resultant supernatant was analysed for ethanol by gas chromatography (GC). The $S$. cerevisiae TISTR 5596 strain was used as the reference (control) ethanol producing strain, and was cultured at $30^{\circ} \mathrm{CT} h o s e$ $S$. cerevisiae strains that produced ethanol at a higher level than the reference strain were further examined for their ethanol production level in molasses medium containing $(\% \mathrm{w} / \mathrm{v})$; molasses 10 and $\left(\mathrm{NH}_{4}\right)_{2} \mathrm{SO}_{4}$ 0.2, $\mathrm{pH} 4.5$.

Comparison of the ethanol production efficacy of $S$. cerevisiae NC027 and the reference $S$. cerevisiae strain (TISTR 5596) was performed by inoculating the inoculum, prepared as above, into $45 \mathrm{ml}$ of the molasses medium in a 125 -ml Duran bottle (final $2.1 \times 10^{6}$ cells $/ \mathrm{ml}$ ), which was then tightly closed and incubated at $30^{\circ} \mathrm{C}$ with $150 \mathrm{rpm}$ agitation. Every $24 \mathrm{~h}$ an aliquot was removed, centrifuged and the cell free supernatant analysed for ethanol content by GC and for residual reducing sugar content by the Somogyi-Nelson method ${ }^{19,22}$.

\section{Characterization of other yeast species isolated}

Those isolated yeasts that were not $S$. cerevisiae, as identified by their 26S rRNA gene sequence analysis, were further examined for their carbon assimilation pattern using the ID 32C kit (bioMerieux, France). Cells grown on YPD agar at $30^{\circ} \mathrm{C}$ for $48 \mathrm{~h}$ were suspended in SSS to a final turbidity of 2 McFarland (MaF) units, transferred to $7 \mathrm{ml}$ of API-C medium and gently mixed, and then $135 \mu \mathrm{l}$ of this cell suspension was transferred into strip cupules of ID $32 \mathrm{C}$ and incubated at $30^{\circ} \mathrm{C}$ for $48 \mathrm{~h}$. The turbidity of the cupules was determined; $(+)$ positive, more turbid than control and $(-)$ negative, less turbid than control. The turbidity result was verified and compared to those of the type strains described in Ref. 9.

\section{RESULTS AND DISCUSSION}

\section{Isolation and identification of yeasts}

In total, 46 yeast isolates were obtained from the 39 CIS samples. They were divided into ten groups (Groups I-X) based on their morphological, physiological and biochemical characteristics (Table 1) and their 26S rRNA (D1/D2 domain) gene sequences.

Group I contained 30 isolates. Colonies were circular, 1-3 mm diameter, cream colour, entire 


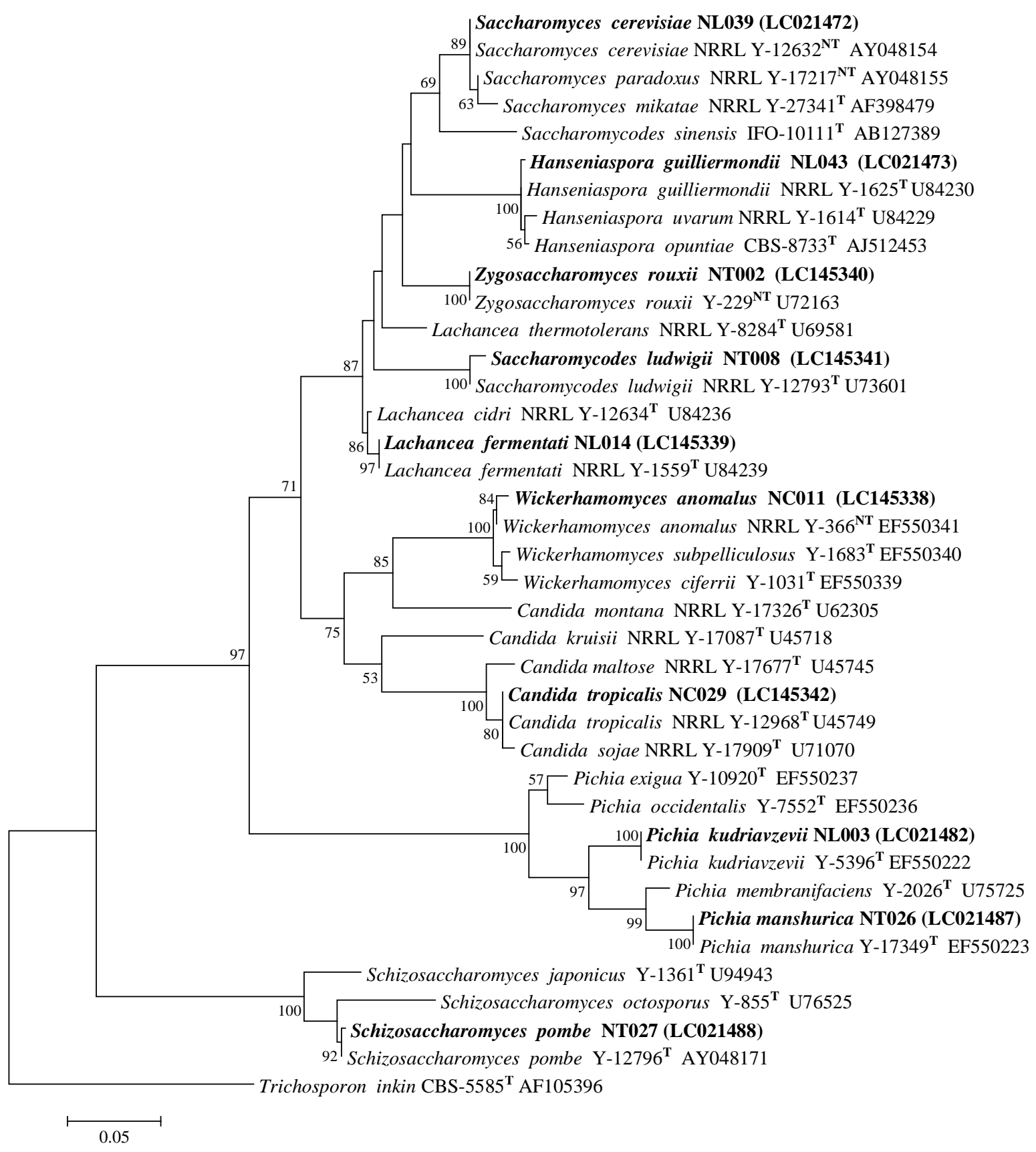

Fig. 1 Phylogenetic tree constructed by the neighbour-joining method based on D1/D2 domain of 26S rRNA gene sequences indicates position of the strong fermenting yeasts isolated from coconut inflorescence sap.

edge. Cells were oval shaped except for isolates NL021 and NC027, which were spherical shaped. Cells reproduced by multilateral budding. The vegetative cell transformed into asci containing 1-4 spherical and smooth ascospores, which didn't liberate. They fermented glucose vigorously, grew at $37^{\circ} \mathrm{C}$, could not grow in vitamin free medium, could not assimilate melibiose or mannitol as a sole carbon source, and assimilated $\left(\mathrm{NH}_{4}\right)_{2} \mathrm{SO}_{4}$ but not $\mathrm{KNO}_{3}$ as the sole nitrogen source. These characteristics confirmed that they were $S$. cerevisiae. Nine of these isolates (NC002, NC006, NC009, NC014, NC015, NC021, NL039, NT028 and NT029) could grow at $40^{\circ} \mathrm{C}$. All of them assimilated glucose, galactose, 
Table 1 Morphological, physiological and biochemical characteristics of the fermenting yeasts isolated in Groups I-X.

\begin{tabular}{|c|c|c|c|c|c|c|c|c|c|c|}
\hline Characteristic & I & II & III & IV & $\mathrm{V}$ & VI & VII & VIII & IX & $\mathrm{X}$ \\
\hline Number of isolates & 30 & 1 & 1 & 1 & 5 & 1 & 2 & 2 & 1 & 2 \\
\hline Cell shape $^{\dagger}$ & SO & $\mathrm{AE}$ & SO & $\mathrm{L}$ & OC & OC & SE & $\mathrm{OE}$ & OC & GE \\
\hline Colony size (mm) & $1-3$ & 1 & 1 & $1-2$ & $1-2$ & $1-2$ & $1-2$ & $1-4$ & $1-2$ & $1-2$ \\
\hline Colony colour & cream & cream & white & cream/tan & cream & cream & cream & cream & $\tan$ & cream \\
\hline Colony margin & entire & entire & entire & entire & entire & entire & entire & lobate & scalloped & entire \\
\hline Budding & M & B & M & $\mathrm{B}$ & M & M & M & M & $M^{1}$ & $\mathrm{~F}$ \\
\hline Pseudohyphae & - & - & simple & short chains & - & - & + & + & + & - \\
\hline Ascospore* & SS & HS & SS & SS & SS & HS & - & SS & HS & GE \\
\hline Growth at $37^{\circ} \mathrm{C}$ & + & - & + & + & - & - & + & + & + & - \\
\hline Growth at $40^{\circ} \mathrm{C}$ & $-(+9)$ & - & + & + & - & - & - & + & + & - \\
\hline$N$-Acetyl-glucosamine & - & - & - & - & - & - & + & + & + & - \\
\hline D-Cellobiose & - & + & - & + & + & + & - & - & - & - \\
\hline Cycloheximide (Actidione) & - & + & - & + & + & - & + & - & - & - \\
\hline D-Galactose & + & - & - & + & + & - & + & - & - & - \\
\hline Glucosamine & - & - & - & - & - & - & - & + & + & - \\
\hline D-Glucose & + & + & + & + & + & + & + & + & + & + \\
\hline Glycerol & $-(+1)$ & - & + & + & - & - & - & + & - & - \\
\hline D-Maltose & + & - & + & - & + & + & + & - & - & - \\
\hline D-Mannitol & - & - & + & - & + & + & + & - & - & - \\
\hline Methyl- $\alpha$-D-glucopyranoside & - & - & - & - & + & + & - & - & - & - \\
\hline Palatinose & - & - & - & - & $-(+1)$ & - & + & - & - & - \\
\hline Potassium 2-ketogluconate & - & + & - & - & + & + & + & - & - & - \\
\hline D-Raffinose & + & - & - & - & + & + & - & - & - & + \\
\hline D-Saccharose (sucrose) & + & - & - & + & + & + & - & - & - & + \\
\hline Sodium glucuronate & - & - & - & - & - & + & - & - & - & - \\
\hline L-Sorbose & - & - & - & - & $-(+1)$ & - & - & - & - & - \\
\hline D-Trehalose & + & - & - & - & + & + & + & - & - & - \\
\hline D-Xylose & - & - & - & - & $-(+1)$ & - & + & - & + & - \\
\hline Galactose & $-(+1)$ & - & - & - & + & - & + & - & - & - \\
\hline Glucose & + & + & + & + & + & + & + & + & $+/ s$ & + \\
\hline Lactose & - & - & - & - & - & - & - & - & - & - \\
\hline Maltose & + & - & + & - & + & + & + & - & - & - \\
\hline Raffinose & + & - & - & + & - & - & - & - & - & - \\
\hline Sucrose & + & - & - & + & + & - & + & - & - & + \\
\hline Trehalose & - & - & - & - & + & - & $+/ s$ & - & - & - \\
\hline
\end{tabular}

I, Saccharomyces cerevisiae; II, Hanseniaspora guilliermondii; III, Zygosaccharomyces rouxii; IV, Saccharomycodes ludwigii; V, Lachancea fermentati; VI, Wickerhamomyces anomalus; VII, Candida tropicalis; VIII, Pichia kudriavzevii; IX, P. manshurica; X, Schizosaccharomyces pombe.

$\dagger$ SO, spherical to ovoid; AE, apiculate elongate; L, lemon shape; OC, ovoid cylindrical; SE, spherical to elongate; OE, ovoid to elongate; GE, globose ellipsoidal.

$*$ M, multilateral; B, bipolar; F, fission.

" SS, spherical and smooth; HS, hat shape; GE, globose ellipsoidal.

maltose, raffinose, sucrose and trehalose, and could ferment glucose, maltose, raffinose and sucrose, but isolate NL039 could also ferment galactose (Table 1). The 26S rRNA (D1/D2) gene sequence of yeasts in this group (Group I) were $99.8-100 \%$ similar to those of S. cerevisiae NRRL Y-12632 ${ }^{\mathrm{NT}}$ (Fig. 1), and so overall were classified as $S$. cerevisiae ${ }^{15}$.

Group II contained one isolate (NL043). Colonies were circular, $1 \mathrm{~mm}$ diameter, cream colour, smooth and slightly raised at the centre. Cell shape was apiculate or elongate, reproduced by bipolar budding, pseudohyphae was absent, and 1-4 hat shape ascospores were released from the mature ascus. It assimilated glucose, cellobiose, cycloheximide (Actidione) and potassium-2ketogluconate, but could only ferment glucose. It shared the same morphological, physiological and biochemical characteristics as $H$. guilliermondii 
NRRL Y-1625 ${ }^{\mathrm{T}}$ (Table 1), while the 26S rRNA (D1/D2) gene sequence was $99.8 \%$ similar to H. guilliermondii NRRL Y- $1625^{\mathrm{T}}$ (Fig. 1). It was, therefore, identified as $H$. guilliermondii ${ }^{2}$.

Group III contained one isolate (NT002). Colonies were circular, smooth, white colour, $1 \mathrm{~mm}$ diameter. Cell shape was spherical to ovoid, reproduced by multilateral budding, and produced a simple form of pseudohyphae. One to four spherical to ovoid ascospores were formed per ascus. It assimilated glucose, glycerol, maltose and mannitol, and fermented glucose and maltose (Table 1). Its 26S rRNA (D1/D2) gene sequence was $99.8 \%$ similar to $Z$. rouxii $\mathrm{Y}-229^{\mathrm{NT}}$ (Fig. 1), but it could grow at $40^{\circ} \mathrm{C}$, which is different to $Z$. rouxii $\mathrm{Y}-229^{\mathrm{NT}}$. It was identified as a new strain of $Z$. rouxii ${ }^{5}$.

Group IV contained one isolate (NT008). Colonies were circular, $1-2 \mathrm{~mm}$ diameter, cream to tan colour. Cells were lemon shaped, reproduced by bipolar budding, showed a few short chains of pseudohyphae, 1-4 spherical and smooth ascospores, ascus did not lyse. It assimilated glucose, galactose, cellobiose, sucrose, cycloheximide (Actidione) and glycerol, and fermented glucose, raffinose a nd s ucrose (Table 1 ). T he $26 \mathrm{~S}$ rRNA (D1/D2) gene sequence was $99.1 \%$ similar to Saccharomycodes ludwigii NRRL Y-12793 ${ }^{\mathrm{T}}$ (Fig. 1), but it could grow at $37-40^{\circ} \mathrm{C}$ which was different to that for Saccharomycodes ludwigii NRRL Y-12793 ${ }^{\mathrm{T}}$. Accordingly, other gene sequences should be analysed and compared to those of Saccharomycodes ludwigii NRRL Y-12793 ${ }^{\mathrm{T}}$, but in the meantime this isolate was identified as a new strain of Saccharomycodes ludwigii ${ }^{18}$.

Group V contained five isolates (NL014, NL032, NL035, NL044, and NT006). Colonies were circular, 1-2 mm diameter, cream coloured. Cell shape was spherical to cylindrical, reproduced by multilateral budding, few or absent pseudohyphae, asci were spherical and smooth. They assimilated glucose, galactose, cellobiose, raffinose, m altose, mannitol and cycloheximide (Actidione), while isolate NL014 could also assimilate sorbose, palatinose and xylose. All of them could ferment glucose, galactose, maltose, sucrose and trehalose (Table 1). Their 26S rRNA (D1/D2) gene sequences were 99.8-100\% similar to L. fermentati NRRL Y-1559 ${ }^{\mathrm{T}}$ (Fig. 1). They were identified as L. fermentati ${ }^{11}$.

Group VI contained one isolate (NC011). Colonies were circular, 1-2 mm diameter, cream colour. Cell shape was spherical to elongate, reproduced by multilateral budding, pseudohyphae were absent, 1-4 hat shape ascospores in each ascus. The isolate could assimilate glucose, galactose, cellobiose, maltose, mannitol, methyl- $\alpha$-Dglucopyranoside, potassium-2-ketogluconate, raffinose, sucrose, sodium glucuronate and trehalose, and could ferment glucose and maltose. The 26S rRNA (D1/D2) gene sequence was $99.8 \%$ similar to W. anomalus NRRL Y-366 ${ }^{\mathrm{NT}}$ (Fig. 1) and had almost the same phenotypic characteristics as that strain (Table 1), and so was identified as W. anomalus ${ }^{8}$.

Group VII contained two isolates (NC029 and NT015). Colonies were circular, 1-2 mm diameter, cream colour. Cell shape was spherical to elongate, reproduced by multilateral budding, ascospore was absent, septate and branched pseudohyphae. They assimilated glucose, galactose, maltose, mannitol, palatinose, $N$-acetyl-glucosamine, cycloheximide (Actidione), potassium-2-ketogluconate, trehalose and xylose, and fermented glucose, galactose, sucrose, maltose and trehalose (Table 1). Their 26S rRNA (D1/D2) gene sequences were identical to Candida tropicalis NRRL Y-12968 ${ }^{\mathrm{T}}$ (Fig. 1). They were identified as Candida tropicalis ${ }^{11}$.

Group VIII contained two isolates (NL003 and NT014). Colonies were circular, lobate margin, 1-4 mm diameter, cream colour. Cell shape was ovoid to elongate, spherical and smooth ascospore, reproduced by multilateral budding, psuedohyphae were abundant and moderately branched. They grew at $37-40^{\circ} \mathrm{C}$, assimilated glucose, $N$-acetylglucosamine, glucosamine and glycerol, and fermented glucose (Table 1). Their 26S rRNA (D1/D2) gene sequence was identical to $P$. kudriavzevii Y$5396^{\mathrm{T}}$ (Fig. 1), and they were identified as P. kudriavzevii $^{7}$.

Group IX contained one isolate (NT026). Colonies were circular, scalloped margin, 1-2 mm diameter, tan colour. Cell shape was ovoid to cylindrical, reproduced by multilateral budding, psuedohyphae appeared when examined under a cover glass, 1-4 hat shaped ascospore liberated from each mature ascus. It could grow at $37-40^{\circ} \mathrm{C}$, assimilated glucose, $\mathrm{N}$-acetyl-glucosamine, glucosamine, and xylose, and very slowly fermented glucose (Table 1). The 26S rRNA (D1/D2) gene sequence was identical to $P$. manshurica $\mathrm{Y}-17349^{\mathrm{T}}$ (Fig. 1), and it was identified as $P$. manshurica ${ }^{7}$.

Group X contained two isolates (NT027 and NT007). Colonies were circular, 1-2 mm diameter, cream colour. Cell shape was globose ellipsoidal, reproduced by binary fission, short and simple pseudohyphae present with 2-4 globose ascospores, asci released the ascospore that might cohere in a small group. They assimilated glucose, raffinose and su- 


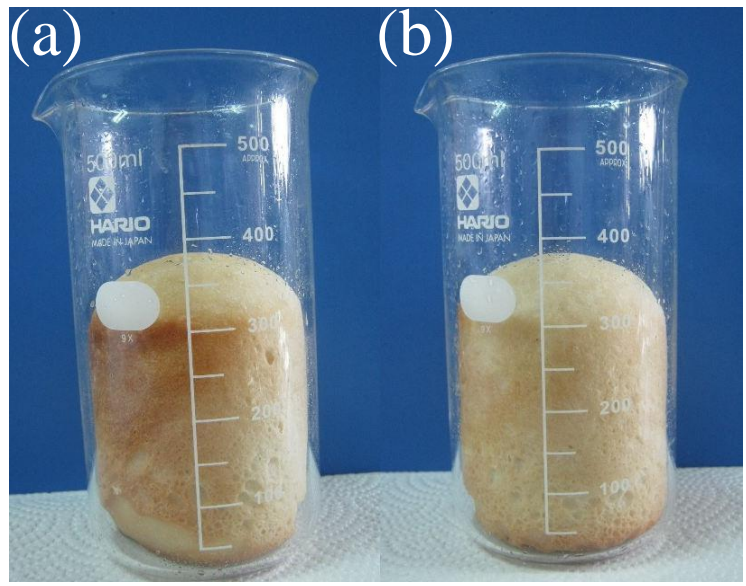

Fig. 2 Comparison of dough leavening capability of (a) S. cerevisiae NC018 and (b) baker's yeast control strain M.

crose, and fermented glucose and sucrose (Table 1). Their 26S rRNA (D1/D2) gene sequence was identical to Schizosaccharomyces pombe Y-12796 ${ }^{\mathrm{T}}$ (Fig. 1), and they were identified as Schizosaccharomyces pombe $e^{16}$.

In some contrast, the microbial flora of fresh CIS in Chennai, India was reported to be less diverse, containing Kloeckera apiculata, Schizosaccharomyces pombe and Candida glabrata ${ }^{6}$.

The $S$. cerevisiae strains obtained in this study (Group I) were then further screened for their thermotolerance and $\mathrm{CO}_{2}$ production level strains. It was found that nine of the 30 strains (NC002, NC006, NC009, NC014, NC015, NC021, NL039, NT028 and NT029) could grow at $40^{\circ} \mathrm{C}$. At $40{ }^{\circ} \mathrm{C}$, strain NT029 produced the highest ethanol level $(64.5 \mathrm{~g} / \mathrm{l})$, which was 1.08 -fold higher than the reference strain (TISTR 5596) at $59.5 \mathrm{~g} / \mathrm{l}$. Seven strains (NL001, NL021, NL026, NL041, NT017, NC018 and NC024) produced $\mathrm{CO}_{2}$ at levels above $80 \mathrm{~g} / \mathrm{l}$. These seven high $\mathrm{CO}_{2}$ producing $\mathrm{S}$. cerevisiae strains were then screened for the desirable characteristics for baker's yeast and ethanol producing strains to examine their commercial potential. A low ethanol production level by $S$. cerevisiae at a high temperature is due to the increased membrane fluidity, to which the yeast responds by changing the membrane fatty acid composition ${ }^{17}$.

\section{Characterization of the seven high $\mathrm{CO}_{2}$ producing S. cerevisiae strains}

Small scale baking revealed that the dough volume baked by strain NC018 was almost the same as those

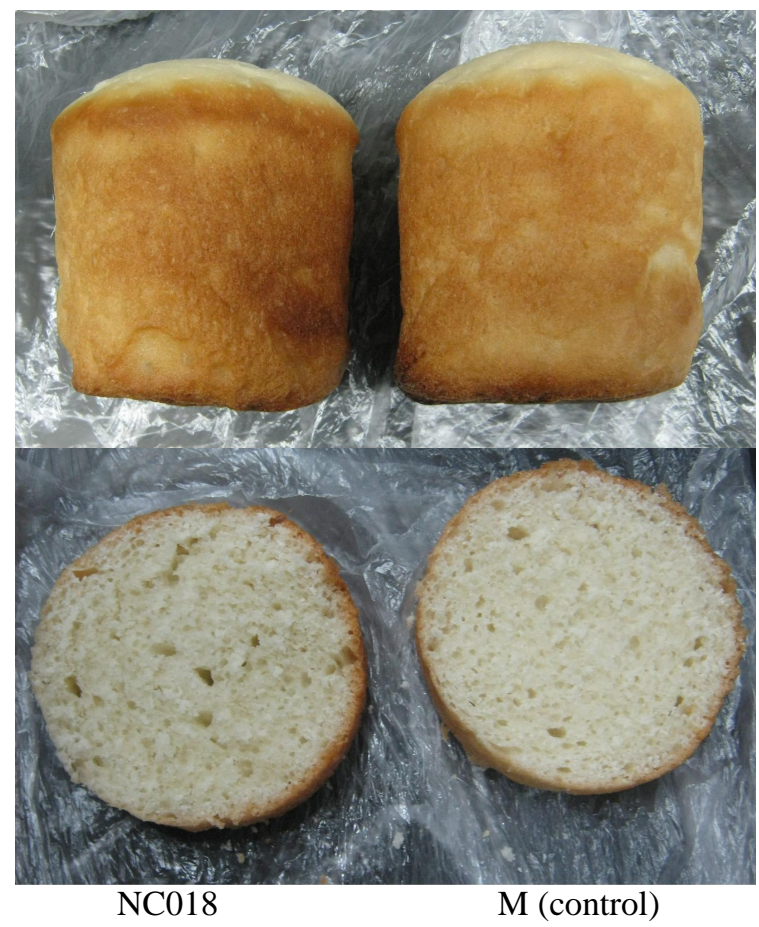

Fig. 3 Comparison of bread texture prepared by S. cerevisiae NC018 and baker's yeast control strain M.

Table 2 Dough volume and cell biomass of the seven high $\mathrm{CO}_{2}$ producing $S$. cerevisiae strains.

\begin{tabular}{lcc}
\hline $\begin{array}{l}\text { Dough } \\
(\mathrm{ml})\end{array}$ & S. cerevisiae & $\begin{array}{c}\text { Cell biomass } \\
(\mathrm{g} \text { wet } / 100 \mathrm{ml})\end{array}$ \\
\hline $278 \pm 1.1^{\mathrm{f}}$ & $\mathrm{NL001}$ & $2.96 \pm 0.04^{\mathrm{bc}}$ \\
$300 \pm 1.5^{\mathrm{e}}$ & $\mathrm{NL021}$ & $2.86 \pm 0.04^{\mathrm{cd}}$ \\
$304 \pm 1.0^{\mathrm{d}}$ & $\mathrm{NL026}$ & $2.63 \pm 0.04^{\mathrm{e}}$ \\
$308 \pm 1.5^{\mathrm{c}}$ & $\mathrm{NL041}$ & $3.16 \pm 0.04^{\mathrm{a}}$ \\
$330 \pm 1.5^{\mathrm{b}}$ & $\mathrm{NC018}$ & $3.06 \pm 0.04^{\mathrm{ab}}$ \\
$310 \pm 1.5^{\mathrm{c}}$ & NC024 & $3.10 \pm 0.10^{\mathrm{a}}$ \\
$310 \pm 2.0^{\mathrm{c}}$ & NC027 & $2.90 \pm 0.10^{\mathrm{cd}}$ \\
$335 \pm 1.7^{\mathrm{a}}$ & M (control) & $2.83 \pm 0.04^{\mathrm{cd}}$ \\
\hline
\end{tabular}

Data are shown as the mean $\pm \mathrm{SD}$, derived from 3 independent repeats. Different letters in each column are significantly different ( $p<0.05$ by DMRT).

baked with Sankyo Yeast M (Table 2 and Fig. 2), the reference baker's yeast. Bread baked by strain NC018 had an elastic sticky texture, which is a good bread texture (Fig. 3). Thus S. cerevisiae NC018 has the potential to be used as baker's yeast. Six of the selected seven high $\mathrm{CO}_{2}$ producing $\mathrm{S}$. cerevisiae strains (not strain NC026) gave a higher cell biomass than the reference baker's yeast (Table 2).

It was previously found that among 13 strains 
of S. cerevisiae isolated from 30 different local fruits and plant parts in Malaysia, five $\mathrm{s}$ trains $\mathrm{h}$ ad a fermentative performance that was better than the commercial baker's yeast $S$. cerevisiae ATCC $62418^{1}$, while the texture of bread made by $S$. cerevisiae strain S6, isolated from sugarcane juice, indicated its potential as a baker's yeast ${ }^{14}$. In addition, two out of ten yeasts screened from decomposed fruit, fermented rice and fruits showed a high potential as a leavening agent in bread dough and were identified as $S$. cerevisiae ${ }^{4}$.

\section{Osmotolerance and ethanol tolerance}

The osmotolerance of the seven high $\mathrm{CO}_{2}$ producing $S$. cerevisiae strains were determined by comparing their growth in medium containing glucose at 24,26 , and $28 \%(\mathrm{w} / \mathrm{v})$ to those of the reference baker's yeast strain. All strains grew better than the reference strain in $28 \%(\mathrm{w} / \mathrm{v})$ glucose medium, while in $26 \%$ and $24 \%(\mathrm{w} / \mathrm{v})$ glucose medium three (NL001, NL041 and NC018) and two (NL001 and NL041) strains grew better than and at the same level as, respectively, the reference baker's yeast strain. However, strains NL001 and NL041 had a higher osmotolerance than the reference strain. None of the seven high $\mathrm{CO}_{2}$ producing $S$. cerevisiae strains had a higher ethanol tolerance in medium containing 10,13 , and $15 \%(\mathrm{v} / \mathrm{v})$ ethanol than the reference ethanol producing strain.

Seven $S$. cerevisiae strains with an ethanol tolerance range of $7-12 \%(\mathrm{v} / \mathrm{v})$ were previously isolated from different fruit samples ${ }^{25}$, revealing the potential of such sources for novel yeast isolates suitable as baker's yeast. Baker's yeast that produced a suitable concentration of ethanol is needed in order to achieve the preferred flavour of bread ${ }^{1}$. However, increasing ethanol levels are toxic to yeast because it causes mitochondrial DNA damage, degrades the cell membrane and finally causes cell death ${ }^{23}$.

\section{Lag period before $\mathrm{CO}_{2}$ production, flocculation capability and flocculation rate}

Acidification of the cultivation media by two strains (NC024 and NC027) was detected faster than that with the reference Sankyo Yeast M and TISTR 5596 strains, suggesting that $\mathrm{NC024}$ and NC027 started fermentation faster than the reference strains. This is a desired character for both baker's and ethanol producing yeasts. All of the seven high $\mathrm{CO}_{2}$ producing $S$. cerevisiae strains could flocculate. Five of these strains (NL021, NL026, NL041, NC018 and NC024) flocculated 1.23-1.61-fold faster than the reference baker's and ethanol producing strains,
Table 3 Comparison of the ethanol production level of the seven high $\mathrm{CO}_{2}$ producing $S$. cerevisiae strains in $10 \%(\mathrm{w} / \mathrm{v})$ molasses medium at $30^{\circ} \mathrm{C}$.

\begin{tabular}{|c|c|c|}
\hline \multirow[t]{2}{*}{ S. cerevisiae strain } & \multicolumn{2}{|c|}{ Ethanol production $(\mathrm{g} / \mathrm{l})$} \\
\hline & $48 \mathrm{~h}$ & $72 \mathrm{~h}$ \\
\hline NL001 & $78.56 \pm 0.22^{c}$ & $84.07 \pm 0.29^{c}$ \\
\hline NL021 & $76.91 \pm 0.88^{\mathrm{e}}$ & $77.68 \pm 0.07^{\mathrm{e}}$ \\
\hline NL026 & $77.74 \pm 0.01^{\mathrm{d}}$ & $84.02 \pm 0.21^{\mathrm{c}}$ \\
\hline NL041 & $74.43 \pm 0.06^{\mathrm{f}}$ & $77.08 \pm 0.07^{f}$ \\
\hline NC018 & $71.81 \pm 0.10^{\mathrm{h}}$ & $82.02 \pm 0.02^{\mathrm{d}}$ \\
\hline NC024 & $73.22 \pm 0.04^{g}$ & $71.96 \pm 0.04^{g}$ \\
\hline NC027 & $88.98 \pm 0.09^{a}$ & $87.57 \pm 0.02^{\mathrm{a}}$ \\
\hline TISTR 5596 & $84.68 \pm 0.12^{b}$ & $86.42 \pm 0.06^{\mathrm{b}}$ \\
\hline
\end{tabular}

Data are shown as the mean $\pm \mathrm{SD}$, derived from 3 independent repeats. Different letters in each column are significantly different $(p<0.05$ by DMRT).

which both took $5.3 \mathrm{~h}$. Self-flocculation is a desired characteristic of $S$. cerevisiae to be used as baker's yeast because it is easy to separate the yeast from the production broth medium and so reduces the cell harvesting cost. However, a slow flocculation rate is a better characteristic for use as an ethanol producing strain as it provides more time for nutrient assimilation and ethanol production.

\section{Ethanol production}

Among the seven high $\mathrm{CO}_{2}$ producing $S$. cerevisiae strains, NC027 produced the highest maximum ethanol yield $(66.93 \mathrm{~g} / \mathrm{l})$ in $18 \%(\mathrm{w} / \mathrm{v})$ glucose containing medium at $30^{\circ} \mathrm{C}$ after $48 \mathrm{~h}$, which was slightly (1.02-fold) higher than the reference ethanol producing TISTR 5596 strain at $65.67 \mathrm{~g} / \mathrm{l}$. Comparison of the ethanol production level in $10 \%$ $(\mathrm{w} / \mathrm{v})$ molasses medium at 48 and $72 \mathrm{~h}$ revealed that the highest ethanol yield $(88.98 \mathrm{~g} / \mathrm{l})$ was produced by strain NC027 at $48 \mathrm{~h}$, some 1.03 -fold higher than the reference strain $(86.42 \mathrm{~g} / \mathrm{l})$ at $72 \mathrm{~h}$ (Table 3).

For the $10 \%(\mathrm{w} / \mathrm{v})$ molasses medium, the ethanol production level by $\mathrm{NC027}$ and the reference strain were comparable using the same inoculum size $\left(2.1 \times 10^{6}\right.$ cells $\left./ \mathrm{ml}\right)$, where it was found that NC027 produced a $22 \%$ higher maximum ethanol yield $(102.26 \mathrm{~g} / \mathrm{l})$ than the reference strain $(84.01 \mathrm{~g} / \mathrm{l})$ at $48 \mathrm{~h}$.

Given that strain NC027 produced a higher ethanol yield than the reference TISTR 5596 strain, flocculated at the same rate and showed the same ethanol tolerance, the strain may have the potential to be used as ethanol producing strain. 


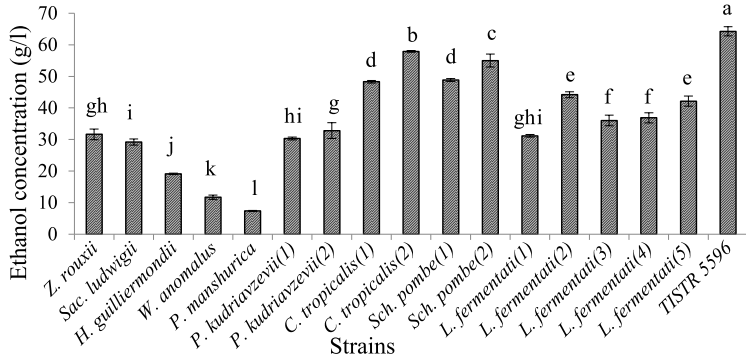

Fig. 4 Comparison of ethanol production of other 9 yeast strains isolated at $30^{\circ} \mathrm{C}, 48 \mathrm{~h}$.

\section{Glycerol assimilation}

Two S. cerevisiae strains (NL010 and NL026) could grow in YNB broth containing 0.5\% (w/v) glycerol as the sole carbon source, giving a cell biomass of 0.66 and $0.42 \mathrm{~g} / 100 \mathrm{ml}$ (wet weight), respectively, after $72 \mathrm{~h}$. This is comparable to that reported for $S$. cerevisiae BY4741 grown in minimal medium containing glycerol as the sole carbon source, which had a specific growth rate of $0.05 \mathrm{~g} / \mathrm{h}^{13}$.

\section{Characterization of the other yeast species (Groups II-X)}

The ethanol production level of the yeasts in Groups II-X at $30^{\circ} \mathrm{C}$ is summarized in Fig. 4 . Strain NC029 (Candida tropicalis) produced the highest ethanol level $(57.93 \mathrm{~g} / \mathrm{l})$, but this was lower than the ethanol producing control strain, TISTR 5596 $(64.29 \mathrm{~g} / \mathrm{l})$. Four strains; NL003 (P. kudriavzevii), NT002 (Z. rouxii), NT008 (Saccharomycodes ludwigii) and NT026 (P. manshurica) could grow at $40^{\circ} \mathrm{C}$, but only strains NT008 and NL003 could produce ethanol (42.2 and $41.0 \mathrm{~g} / 1$, respectively) at $40^{\circ} \mathrm{C}$.

Acknowledgements: This study was financially supported by the Higher Education Research Promotion and National Research University Project of Thailand, Office of the Higher Education Commission (EN 275B-56).

\section{REFERENCES}

1. Asyikeen NZ, Ma'raruf AG, Sahilah AM, Mohd KA, Wan Aida WM (2013) A new source of Saccharomyces cerevisiae as a leavening agent in bread making. Int Food Res $J$ 20, 967-73.

2. Cadez N, Smith MT (2011) Hanseniaspora Zikes (1912). In: Kurtzman CP, Fell JW, Boekhout T (Eds) The Yeasts, a Taxonomic Study, 5th edn, Elsevier, Amsterdam, pp 421-34.

3. Chatzifragkou A, Makri A, Belka A, Bellou S, Mavrou M, Mastoridou M, Mystrioti P, Onjaro G, et al (2011) Biotechnological conversions of biodiesel derived waste glycerol by yeast and fungal species. Energy 36, 1097-108.

4. Jahan N, Azmuda N, Khan AR (2007) Isolation and identification of indigenous baker's yeast. Bangladesh $J$ Microbiol 24, 65-6.

5. James SA, Stratford M (2011) Zygosacchromyces Barker (1901). In: Kurtzman CP, Fell JW, Boekhout $\mathrm{T}$ (Eds), The Yeasts, a Taxonomic Study, 5th edn, Elsevier, Amsterdam, pp 937-47.

6. Kalaiyarasi K, Sangeetha K, Rajarajan S (2013) A comparative study on the microbial flora of the fresh sap from cut inflorescence and fermented sap (toddy) of Borrassus flabellifer Linn. (palmyrah tree) and of Cocos nucifera Linn. (coconut tree) to identify the microbial fermenters. Int $J$ Res Pure Appl Microbiol 3, 43-7.

7. Kurtzman CP (2011) Pichia Hansen EC (1904). In: Kurtzman CP, Fell JW, Boekhout T (Eds), The Yeasts, a Taxonomic Study, 5th edn, Elsevier, Amsterdam, pp 685-707.

8. Kurtzman CP (2011) Wickerhamomyces Kurtzman, Robnett \& Basehoar-Power (2008). In: Kurtzman CP, Fell JW, Boekhout T (Eds), The Yeasts, a Taxonomic Study, 5th edn, Elsevier, Amsterdam, pp 899-917.

9. Kurtzman CP, Fell JW, Boekhout T (2011) Methods for isolation, phenotypic characterization and maintenance of yeast. In: Kurtzman CP, Fell JW, Boekhout T (Eds), The Yeasts, a Taxonomic Study, 5th edn, Elsevier, Amsterdam, pp 87-110.

10. Kurtzman CP, Robnett CJ (1998) Identification and phylogeny of ascomycetous yeast from analysis of nuclear large subunit (26S) ribosomal DNA partial sequences. Antonie Leeuwenhoek 73, 331-71.

11. Lachance MA, Kurtzman CP (2011) Lachancea Kurtzman (2003). In: Kurtzman CP, Fell JW, Boekhout T (Eds), The Yeasts, a Taxonomic Study, 5th edn, Elsevier, Amsterdam, pp 511-9.

12. Law SV, Abu Bakar F, Mat Hashim D, Abdul Hamid A (2011) Popular fermented foods and beverages in Southeast Asia. Int Food Res $J$ 18, 475-84.

13. Lu LR, Oszust G, Hudson C (2005) The YJR127C/ZMS1 gene product is involved in glycerol-based respiratory growth of the yeast Saccharomyces cerevisiae. Curr Genet 48, 235-46.

14. Mamum Or Rashid ANM, Biplab KD, Nurul AC, Momtaz FW, Kamruzzaman P (2013) Exploration of potential baker's yeast from sugarcane juice: optimization and evaluation. Pak J Biol Sci 39, 217-26.

15. Martini AV, Martini A (2011) Saccharomyces Meyen ex Reess (1870). In: Kurtzman CP, Fell JW, Boekhout T (Eds), The Yeasts, a Taxonomic Study, 5th edn, Elsevier, Amsterdam, pp 733-46.

16. Martini AV, Martini A (2011) Schizosaccharomyces Lindner (1893). In: Kurtzman CP, Fell JW, Boekhout T (Eds), The Yeasts, a Taxonomic Study, 5th edn, Elsevier, Amsterdam, pp 779-84.

17. Mehdikhani P, Bari MR, Hovsepyan H (2011) Screen- 
ing of Saccharomyces cerevisiae for high tolerance of ethanol concentration and temperature. Afr J Microbiol Res 5, 2654-60.

18. Mills KB, Stratford M, Miller MW (2011) Saccharomycodes EC Hansen (1904). In: Kurtzman CP, Fell JW, Boekhout T (Eds), The Yeasts, a Taxonomic Study, 5th edn, Elsevier, Amsterdam, pp 747-50.

19. Nelson CR, Courter ML (1954) Ethanol by hydration of ethylene. Chem Eng Progr 50, 526-32.

20. Oda Y, Ouchi K (1989) Principal-component analysis of the characteristics desirable in baker's yeasts. Appl Environ Microbiol 55, 1495-9.

21. Saitou N, Nei M (1987) The neighbor-joining method: A new method for reconstructing phylogenetic trees. Mol Biol Evol 4, 406-25.

22. Somogyi M (1952) Notes on sugar determination. $J$ Biol Chem 195, 19-23.

23. Swiecilo A, Krawiec Z, Wawryn J, Bartosz G (2000) Effect of stress on the life span of the yeast Saccharomyces cerevisiae. Acta Biochim Pol 47, 355-64.

24. Thompson JD, Gibson TJ, Plewniak F, Jeanmougin F, Hoggins JD (1997) The CLUSTAL X windows interface: flexible strategies for multiple sequence alignment aided by quality analysis tools. Nucleic Acid Res 25, 4876-82.

25. Tikka C, Osuru HP, Atluri N, Raghavulu PCV, Yellapu NK, Mannur IS, Prasad UV, Aluru S, et al (2013) Isolation and characterization of ethanol tolerant yeast strains. Bioinformation 9, 421-25. 